\title{
PERAN CORPORATE SOCIAL RESPONSIBILITY DAN TAX AVOIDANCE DALAM MEMPENGARUHI GOOD CORPORATE GOVERNANCE TERHADAP VALUE CREATION
}

\author{
Yenni Mangoting1 \\ Fakultas Bisnis dan Ekonomi \\ Universitas Kristen Petra \\ yenni@petra.ac.id \\ Venny Agustine Gozal ${ }^{3}$ \\ Fakultas Bisnis dan Ekonomi \\ Universitas Kristen Petra \\ m32415078@john.petra.ac.id
}

\author{
Jennifer Priscilla Badalu ${ }^{2}$ \\ Fakultas Bisnis dan Ekonomi \\ Universitas Kristen Petra \\ m32415100@john.petra.ac.id
}

\author{
Stephen Widjaya Pranata ${ }^{4}$ \\ Fakultas Bisnis dan Ekonomi \\ Universitas Kristen Petra \\ m32415031@john.petra.ac.id
}

\begin{abstract}
ABSTRAK
Penelitian bertujuan untuk menguji apakah tanggung jawab sosial perusahaan dan penghindaran pajak dapat memediasi hubungan tata kelola perusahaan dengan penciptaan nilai. Teknik analisis data yang digunakan adalah regresi linear berganda dengan sampel 573 perusahaan multi-sektor yang terdaftar di BEI. Hasil penelitian menunjukkan bahwa kegiatan tanggung jawab sosial perusahaan, penghindaran pajak, dan tata kelola perusahaan berpengaruh pada penciptaan nilai. Selain itu, penghindaran pajak dapat memediasi hubungan antara tata kelola perusahaan terhadap penciptaan nilai. Di sisi lain, penelitian ini membuktikan bahwa penerapan tanggung jawab sosial perusahaan tidak berdampak pada hubungan antara tata kelola perusahaan yang baik dan penciptaan nilai.
\end{abstract}

Kata Kunci: tata kelola perusahaan; tanggung jawab sosial perusahaan; penghindaran pajak; penciptaan nilai.

\begin{abstract}
This study aims to examine whether corporate social responsibility and tax avoidance can mediate the relationship between corporate governance and value creation. The data analysis technique used is multiple linear regression with a study sample of 573 multi-sector companies that listed on the Indonesia Stock Exchange. The results of the study show that corporate social responsibility activities, tax avoidance, and corporate governance have an effect on value creation. Furthermore, tax avoidance can mediate the relationship between corporate governance and the proportion of value. On the other hand, this research shows that corporate social responsibility does not affect the relationship between good corporate governance and value creation.
\end{abstract}

Keywords: good corporate governance; corporate social responsibility; tax avoidance; value creation.

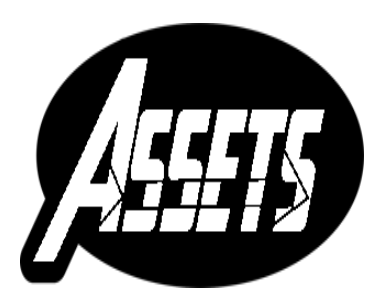

ASSETS

Jurnal Akuntansi dan Pendidikan Vol. 8 No. 2

Hlmn. 146-156

Madiun, Oktober 2019 p-ISSN: 2302-6251 e-ISSN: 2477-4995

Artikel masuk:

22 April 2019

Tanggal diterima:

19 Oktober 2019 


\section{PENDAHULUAN}

Peraturan Otoritas Jasa Keuangan (OJK) Nomor 30/POJK.05/2014 mengenai tata kelola perusahaan yang baik bagi perusahaan sebagai struktur yang diterapkan dalam perusahaan untuk meningkatkan pencapaian target hasil usaha dan nilai perusahaan bagi seluruh stakeholders secara akuntabel dan berlandaskan peraturan perundangundangan serta nilai etika. Stakeholders dalam konteks ini adalah pihak yang memiliki peran penting terhadap perusahaan, baik langsung atau tidak langsung, antara lain debitur, anggota/pemegang saham, karyawan, kreditur, penyedia barang dan jasa, dan/atau pemerintah. Peraturan ini juga mengatur mengenai empat prinsip good governance, yaitu keterbukaan, akuntabilitas, kemandirian, dan kesetaraan. Implementasi good governance diyakini dapat mengantisipasi tindakan oportunis yang mungkin dilakukan oleh manajemen untuk kepentingan pribadi seperti dalam penjelasan (Jensen \& Meckling, 1976) bahwa good governance adalah mekanisme untuk mengurangi konflik keagenan yang timbul antara manajemen sebagai agen dan pemegang saham sebagai prinsipal. Reduksi terhadap konflik keagenan dapat menimbulkan kepercayaan pemegang saham. Perusahaan dianggap telah mengimplementasikan prinsip transparansi yang memfokuskan pada keterbukaan informasi dalam proses pengambilan keputusan sehingga berdampak pada kepercayaan pemegang saham (Mahrani \& Soewarno, 2018; Retno M. \& Priantinah, 2012).

Mekanisme pengawasan dan pemantauan manajemen secara efektif yang dilaksanakan oleh dewan komisaris independen sebagai implementasi prinsip fungsi pengawasan menurut (Richardson, Taylor, \& Lanis, 2013) dapat mengurangi motivasi perusahaan untuk melakukan tax avoidance. (Lanis \& Richardson, 2011) juga menekan peran penting komisaris independen dalam fungsi good governance perusahaan. Rasio komisaris independen yang lebih besar berdampak positif pada pencegahan tindakan oportunis manajemen melalui tax avoidance. Namun demikian, (Dewi \& Sari, 2015) menjelaskan, bahwa meskipun rasio dewan komisaris independen besar tetapi secara jumlah dianggap tidak mampu mengimbangi dominasi shareholders mayoritas dalam pengambilan keputusan strategis.

(J. B. Kim, Li, \& Zhang, 2011) juga mencermati dampak negatif jatuhnya harga saham sebagai akibat tindakan tax avoidance yang dilakukan secara agresif. Arus kas negatif akibat kerugian operasi perusahaan ditutupi oleh penghematan pembayaran pajak melalui tax avoidance. Namun tindakan tersebut justru menjadi sinyal negatif yang ditangkap oleh pemegang saham dan berdampak pada jatuhnya harga saham perusahaan. (Kiesewetter \& Manthey, 2017) juga menegaskan bahwa meskipun dapat mengurangi pembayaran pajak perusahaan, namun strategi tax avoidance tersebut tidak memberikan nilai tambah bagi perusahaan. Penghematan yang diperoleh tidak sebesar biaya monitoring yang harus dikeluarkan untuk meminimalkan konflik keagenan.

(Gholami, 2011) mengaitkan corporate social responsibility dengan strategi bisnis perusahaan untuk mempertahankan kelangsungan hidupnya ditengah-tengah masyarakat. Perusahaan yang mengelaborasikan aktivitas corporate social responsibility dan strategi perusahaan menurut (Husted \& Allen, 2007) misalnya dalam inovasi produk yang sesuai kebutuhan konsumen akan berdampak pada penciptaan nilai bagi perusahaan. Meskipun tidak dapat dipungkiri adanya pandangan negatif terhadap corporate social responsibility yang diduga hanya aktivitas window dressing untuk menutupi kesalahaan pengelolaan perusahaan yang tidak sesuai dengan standar yang ditetapkan oleh otoritas perumus regulasi.

Salah satu tujuan good governance yang diungkapkan dalam peraturan OJK nomor 30/POJK.05/2014 adalah untuk mengoptimalkan nilai perusahaan bagi 
pemangku kepentingan, seperti debitur, kreditur, dan/atau pemangku kepentingan lainnya. Berdasarkan tujuan ini dapat disimpulkan bahwa corporate social responsibility dapat meningkatkan value creation. (Stuebs \& Sun, 2015) memfokuskan adanya keseimbangan antara tujuan ekonomi dan sosial yang berusaha diciptakan melalui mekanisme good governance. Perusahaan yang mengimplementasikan good governance dengan baik akan memiliki kinerja tanggung jawab sosial yang baik. Artinya, perusahaan dianggap telah melaksanakan prinsip good governance, yaitu pertanggungjawaban (responsibility) yang berarti adanya kesesuaian pengelolaan perusahaan dengan peraturan perundang-undangan dan nilai etika. Prinsip tersebut relevan dengan konsep corporate social responsibility yang berorientasi pada kesejahteraan pemangku kepentingan.

Good governance adalah mekanisme yang dapat memecahkan konflik antara prinsipal dan manajemen sebagai agensi. Konflik timbul karena manajemen memiliki informasi lebih yang tidak dimiliki oleh pemangku kepentingan lain, sehingga terjadi asimetri informasi. Asimetri informasi memberikan peluang bagi manajemen untuk melakukan pengelolaan pajak secara agresif melalui tindakan tax avoidance. Konflik karena kesempatan melakukan tindakan oportunis inilah yang akan diantisipasi melalaui mekanisme good governance karena good governance yang mengandung prinsip-prinsip transparency, accountability, responsibility, independency, dan fairness dianggap dapat menciptakan nilai perusahaan sehingga dapat memenuhi harapan pemegang saham. Dalam konsep pembangunan berkelanjutan, perusahaan tidak semata-mata mengambil keputusan berdasarkan pertimbangan keuntungan, namun juga berdasarkan konsekuensi sosial dan lingkungan untuk jangka panjang. Demi mencapai tujuan tersebut (Said, Joseph, \& Sidek, 2017) menekankan pentingnya perusahaan mengimplementasikan pelaksanaan good governance, karena prinsipprinsip dalam good governance, bersinergi dengan konsep corporate social responsibility.

Dalam konteks penelitian ini, perilaku agresif perusahaan melalui tax avoidance sebagai variable mediasi dapat berdampak positif dan negatif bagi pelaksanaan good governance yang berpengaruh terhadap peningkatan dan penurunan nilai perusahaan (Santa \& Rezende, 2016). Dengan good governance, seharusnya perusahaan mampu mengendalikan kebijakan agresif melalui tindakan tax avoidance yang berdampak pada nilai perusahaan. Artinya, good governance yang baik dalam perusahaan harusnya berjalan efektif sebagai sistem pengawasan dan pencegahan tindakan yang dapat mengurangi kepercayaan para stakeholders sehingga mempengaruhi keputusan investasi. Di sisi yang lain, perusahaan dengan tata kelola yang baik sewajarnya dapat memaksimalkan program corporate social responsibility sebagai bagian dari pelaksanaan prinsip pertanggungjawaban perusahaan dengan menciptakan keseimbangan antara pemenuhan kebutuhan manajemen dan stakeholders yang berdampak pada peningkatan nilai perusahaan yang diharapkan meningkatkan nilai perusahaan (Retno M. \& Priantinah, 2012).

Pengaruh mediasi yang diuji dalam penelitian ini menjadi pembeda dibanding penelitian sebelumnya yang lebih memfokuskan pada penelitian parsial untuk mengetahui pengaruh good governance, corporate social responsibility, dan tax avoidance terhadap value creation. Berdasarkan latar belakang di atas, penelitian ini bertujuan untuk mengetahui apakah mekanisme good governance dapat mempengaruhi peningkatan nilai perusahaan atau value creation secara langsung atau tidak melalui corporate social responsibility. Selanjutnya penelitian ini juga bertujuan untuk mengetahui apakah mekanisme good corporate governance dapat mempengaruhi peningkatan nilai perusahaan atau value creation secara langsung atau tidak melalui tax avoidance. 


\section{METODE PENELITIAN}

Penelitian ini menggunakan data dari laporan keuangan tahunan yang tersedia di Bursa Efek Indonesia (BEI), sektor yang dipilih adalah sektor manufaktur, jasa, dan dagang karena ketiga sektor ini memiliki banyak perusahaan dan data yang lebih bervariasi. Total seluruh jumlah data adalah 1338 perusahaan multi-sektor go public yang terdaftar di BEI tahun 2015-2017. Berdasarkan kriteria seleksi populasi, sample penelitian adalah 573 perusahaan seperti yang ad pada tabel 1 .

\section{Tabel 1. Populasi dan Sampel Penelitian}

\begin{tabular}{lc}
\hline Keterangan & Jumlah Sample \\
\hline Perusahaan multisektor go public yang terdaftar di BEI 2015-2017 & 1338 \\
Perusahaan yang tidak memenuhi kriteria: & \\
Perusahaan multi-sektor go public yang tidak memiliki informasi & 321 \\
GCG yang lengkap & 209 \\
$\begin{array}{l}\text { Perusahaan multi-sektor go public yang tidak memiliki informasi } \\
\text { CSR yang lengkap }\end{array}$ & 235 \\
Perusahaan multi-sektor go public yang tidak memiliki informasi \\
market value of firm dan book value of total asset
\end{tabular}

Variabel penelitian ini adalah tax avoidance, value creation, good governance, dan corporate social responsibility. Untuk menganalisis pengaruh good governance, corporate social responsibility, tax avoidance, dan value creation, teknik analisis data yang digunakan adalah regresi linear berganda dan Uji Sobel dilakukan untuk memastikan apakah tax avoidance dan corporate social responsibility mampu memediasi hubungan corporate governance dan value creation.

Dyreng, Hanlon, \& Maydew, (2008) yang menjelaskan, bahwa tax avoidance bagian dari evaluasi sejauh mana pilihan strategi bisnis perusahaan berdampak pada kewajiban membayar pajak. Implementasi tax avoidance biasanya memanfaatkan kelemahan-kelemahan (grey area) hukum pajak sehingga tindakannya tidak melanggar hukum. Tax avoidance diukur menggunakan ETR (Effective Tax Rate). ETR adalah tarif pajak yang terjadi dan dihitung dengan membandingkan beban pajak dengan laba komersial perusahaan. Dari definisi tersebut, ETR bertujuan untuk mengetahui jumlah persentase perubahan sebenarnya dalam membayar pajak terdahap laba komersial suatu perusahaan.

Sherman (2010) menjelaskan bahwa value creation berbeda dengan laba perusahaan secara umum. Value creation mencakup perspektif yang lebih luas karena berkaitan dengan penciptaan nilai perusahaan dalam rangka peningkatan kekayaan dan kesejahteraan stakeholder. Value creation diukur menggunakan Tobin's q dengan membandingkan nilai antara market value of firm dan book value of firm. Menurut Sudiyatno \& Puspitasari (2010), jika nilai pasar sewaktu-waktu berubah dan berpotensi untuk merefleksikan aset yang tercatat pada suatu perusahaan maka Tobin's q sama dengan 1. Jika Tobin's q lebih besar dari 1, maka nilai pasar lebih besar dari nilai aset perusahaan yang tercatat. Hal ini menandakan bahwa harga saham tinggi (overvalued), apabila tobins'q kurang dari 1, nilai pasarnya lebih kecil dari nilai tercatat aset perusahaan. Ini menandakan bahwa harga saham rendah (undervalued).

Good corporate governance secara umum adalah suatu mekanisme yang bertujuan untuk menyeimbangkan antara tindakan dan pilihan manajer dengan kepentingan shareholders (Susanti, 2011). Selain itu, Good corporate governance merupakan proses 
terstruktur yang digunakan untuk menjalankan bisnis secara bertanggung jawab dalam rangka meningkatkan kemakmuran dan merealisasikan kepentingan pemegang saham. Orientasi dari corporate governance adalah tercapainya kepentingan pemegang saham sehingga corporate governance merupakan berbagai kebijakan atau aturan-aturan yang dibangun untuk memastikan bahwa kepentingan pemegang saham bisa tercapai. Diukur menggunakan GCG Score, yang diperoleh dari GCG Index yang memiliki 47 indikator penilaian. Indikator tersebut mewakili setiap bagian dari GCG.

Corporate social responsibility merupakan usaha yang dilakukan oleh perusahaan untuk bertanggung jawab terhadap keseimbangan serta integrasi antara kepentingan lingkungan dan social. Corporate social responsibility merupakan usaha yang dilakukan oleh perusahaan untuk bertanggung jawab atas keseimbangan serta integrasi antara kepentingan lingkungan dan sosial yang ada di lingkungan bisnisnya, dengan kepentingan ekonomi yang dipunyai oleh perusahaan (Brown \& Forster, 2013). Aktivitas corporate social responsibility adalah upaya menjembatani pertemuan kepentingan perusahaan dan para stakeholder yang berpartisipasi menciptakan peningkatan kinerja perusahaan. Diukur menggunakan CSR Score, yang diperoleh dari corporate social responsibility index yaitu Global Reporting Initiative G4 yang memiliki 91 item

\section{HASIL PENELITIAN DAN PEMBAHASAN}

Hasil pengujian statistik deskriptif dari variabel good governance, value creation, tax avoidance, dan corporate social responsibility pada perusahaan multi sektor yang terdaftar di BEI tahun 2015-2017 disajikan dalam tabel 2.

Tabel 2. Statistik Deskriptif

\begin{tabular}{cccccc}
\hline & $\mathrm{N}$ & Minimum & Maximum & Mean & Std. Deviation \\
\hline TAV & 573 & 0 & 0,92 & 0,27 & 0,162 \\
(EFTAXRate) & 573 & 0,001 & 8,04 & 0,19 & 0,453 \\
Value_Creation & 573 & 0,033 & 0,36 & 0,17 & 0,062 \\
CSR & 573 & 0,077 & 0,92 & 0,39 & 0,139 \\
GCG & 573 & & & & \\
Valid N (listwise) & & &
\end{tabular}

Dari data yang ada di tabel 2, variabel tax avoidance, good corporate governance dan corporate social responsibility memiliki nilai rata-rata yang lebih besar dari nilai standar deviasi artinya rata-rata perusahaan yang terdaftar di BEI menjalankan prinsip good corporate governance dan corporate social responsibility sebesar dengan kapasitasnya, sedangkan untuk nilai rata-rata tax avoidance sebesar 0,27 menunjukan bahwa perusahan melakukan tax avoidance sehingga dapat disimpulkan ketiga variabel ini memiliki variansi data dengan fluktuatif stabil. Namun, untuk variabel value creation bisa dilihat bahwa nilai rata-rata lebih kecil dari nilai standar deviasi sehingga dapat disimpulkan bahwa variabel ini memiliki variansi data dengan fluktuatif tinggi.

\section{Pengujian Analisis Jalur (Path Analysis)}

Uji Analisis Jalur (path analysis) bertujuan untuk menganalisis pengaruh langsung dan tidak langsung good corporate governance terhadap value creation dengan corporate social responsibility dan tax avoidance sebagai variabel mediasi ada pada tabel 3. Persamaan regresi struktur I , II, III, IV sebagai berikut: 


$$
\begin{array}{ll}
\text { Struktur I } & : \mathrm{TAV}=\beta_{\mathrm{GCG}}+e_{1} \ldots \ldots \ldots \\
\text { Struktur II } & : \mathrm{VC}=\beta_{G C G}+\beta_{T A}+e . . . \\
\text { Struktur III } & : \mathrm{CSR}=\beta_{\mathrm{GCG}}+e_{3} \ldots \ldots \ldots \\
\text { Struktur IV } & : \mathrm{VC}=\beta_{G C G}+\beta_{C S R}+e_{4}
\end{array}
$$

\begin{tabular}{|c|c|c|c|c|c|c|c|}
\hline \multirow[t]{2}{*}{ Struktur } & \multirow{2}{*}{\multicolumn{2}{|c|}{ Variabel }} & \multicolumn{2}{|c|}{$\begin{array}{l}\text { Unstandardized } \\
\text { Coefficients }\end{array}$} & \multicolumn{3}{|c|}{ Standardized Coefficients } \\
\hline & & & B & Std Error & Beta & $\mathrm{t}$ & Sig \\
\hline I & GCG & TAV & $-0,166$ & 0,065 & 0,106 & -2549 & 0,011 \\
\hline II & GCG & VC & 1,043 & 0,089 & 0,441 & 11687 & 0 \\
\hline II & TAV & VC & 0,099 & 0,049 & 0,076 & 2006 & 0,045 \\
\hline III & GCG & CSR & $-0,042$ & 0,02 & 0,095 & -2089 & 0,037 \\
\hline IV & GCG & VC & 1029 & 0,089 & 0,435 & 11562 & 0 \\
\hline IV & CSR & VC & 0,097 & 0,049 & 0,075 & 1982 & 0,048 \\
\hline
\end{tabular}

Tabel 3. Hasil Uji Analisis Jalur

\section{Pengaruh Good Governance Terhadap Tax Avoidance}

Penelitian ini membuktikan bahwa good corporate governance memiliki pengaruh negatif terhadap ETR, artinya semakin baik implementasi good corporate governance dalam perusahaan justru meningkatkan agresivitas tax avoidance, karena nilai ETR yang rendah menunjukkan tingkat tax avoidance tinggi. Hasil ini menjelaskan bahwa implementasi good corporate governance yang baik tidak berdampak dalam mencegah praktik tax avoidance yang agresif. Beberapa penelitian mendukung hasil ini dengan argumentasi bahwa proporsi dewan komisaris independen yang menjalankan fungsi pengawasan tidak mampu mengimbangi dominasi pemegang saham mayoritas dalam pengambilan keputusan strategis (Retno M. \& Priantinah, 2012) menjelaskan adanya konflik kepentingan antara kebutuhan mendapatkan laba dengan kebutuhan investasi yang besar untuk membiayai aktivitas pelaksanaan good corporate governance. Perusahaan dalam konteks penelitian pada satu sisi tetap melakukan kepatuhan dengan mengimplementasikan tata kelola perusahaan yang baik, tetapi pada sisi yang berbeda, perusahaan tetap bersikap rasional oportunis melalui pengindaran pajak agresif untuk mendapatkan peningkatan laba.

\section{Pengaruh Good Governance Terhadap Value Creation}

Hasil penelitian ini menunjukkan good corporate governance memiliki pengaruh positif terhadap value creation, yang artinya semakin baik good governance dalam perusahaan akan menigkatkan nilai perusahaan. Ketatnya pengelolaan manajemen perusahaan dan pengambilan keputusan dalam menentukan kebijakan perusahaan yang baik mampu meningkatkan nilai perusahaan. Salah satu unsur dalam good corporate governance seperti efektifitas pengawasan dewan komisaris terhadap kinerja manajemen dalam hal pembuatan kebijakan, pengawasan dalam aktivitas perusahaan serta pengambilan keputusan manajemen telah dilakukan dan berjalan baik. Kondisi tersebut memberi dampak pada berkurangnya asymmetry information sehingga informasi yang diterima investor sesuai dengan keadaan perusahaan yang sebenarnya (Hasan \& Butt, 2009). Demikian juga (Wahyudin \& Solikhah, 2017) yang mendukung penelitian ini dengan argumentasi bahwa perusahaan-perusahaan yang terdaftar dan berpartisipasi dalam corporate governance perception index mengalami peningkatan kualitas dan kuantitas kinerja keuangan yang diukur dengan ROA dan ROE. 
Penelitian ini membuktikan bahwa good corporate governance adalah sistem yang mampu meredakan konflik agensi yang timbul antara manajemen dan shareholder (Ammann, Oesch, \& Schmid, 2010). Ketika konflik karena perbedaan kepentingan dapat teratasi melalui mekanisme good corporate governance, hal tersebut berdampak pada kenaikan harga saham menjadi berlipat ganda, karena pemegang saham memperoleh informasi lengkap yang dapat diandalkan untuk pengambilan keputusan (Jensen \& Meckling, 1976). Penelitian ini didukung oleh (Muryati \& Suardikha, 2014), bahwa kepemilikan manajerial sebagai bagian dari unsur good corporate governance dapat menengahi kepentingan manajer dengan pemegang saham sehingga berdampak positif pada peningkatan nilai perusahaan. Penilaian value creation dengan menggunakan nilai tobin's $Q$ menitikberatkan pada pembentukan nilai pasar perusahaan, yang artinya bagaimana perusahaan dapat menciptakan citra positif perusahaan di mata stakeholders khususnya pemegang saham, sehingga penilaian tidak fokus pada aspek fundamental. Implementasi good corporate governance akan tercermin melalui pengelolaan bisnis pada semua aspek dalam perusahaan sehingga membentuk kinerja positif perusahaan bagi investor.

\section{Pengaruh Coporate Governance Terhadap Corporate Social Responsibility}

Penelitian ini mengungkapkan adanya pengaruh negatif good corporate governance terhadap corporate social responsibility, artinya semakin baik implementasi good corporate governance maka semakin rendah aktivitas corporate social responsibility perusahaan. Penelitian ini sejalan dengan (Purbopangestu \& Subowo, 2014) yang menjelaskan bahwa rendahnya kegiatan corporate social responsibility perusahaan karena manajer lebih mementingkan kepentingan sendiri dibandingkan pemenuhan kepentingan para stakeholders melalui kegiatan sosial tersebut. Selain itu, dewan komisaris tidak memprioritaskan kebijakan sosial perusahaan, karena apabila intensitas corporate social responsibility terlalu tinggi, maka komisaris independen cenderung memberikan nasihat kepada pemegang saham untuk menekan pengelolaan dana corporate social responsibility yang dianggap mengganggu cash flow perusahaan. Selain itu, dalam pandangan (Ramdhaningsih \& Utama, 2013) sebaik apapun implementasi good corporate governance, aktivitas corporate social responsibility hanya merupakan kegiatan yang bersifat sukarela dan tidak memberikan konsekuensi hukuman bagi perusahaan yang tidak sepenuhnya melakukan aktivitas tersebut.

\section{Pengaruh Corporate Social Responsibility Terhadap Value Creation}

Penelitian ini mengungkapkan bahwa corporate social responsibility memiliki pengaruh positif terhadap value creation yaitu tingginya aktivitas corporate social responsibility mampu meningkatkan nilai perusahaan. Adanya kegiatan corporate social responsibility menujukan suatu perusahaan berusaha image yang baik sebagai nilai tambah kepada para stakeholdres yang telah berkontribusi bagi peningkatan kinerja perusahaan sehingga meningkatkan nilai perusahaan. Kegiatan sosial yang dilakukan perusahaan juga mampu mendatangkan dukungan positif dari pihak eksternal untuk nilai perusahaan.

Hasil penelitian ini sejalan dengan pendapat Mahrani \& Soewarno (2018) yang mengemukakan bahwa aktivitas corporate social responsibility juga dianggap positif bagi investor sehingga mampu meningkatkan citra perusahaan menjadi lebih baik dan menarik minat pada investor sehingga berdampak pada nilai saham perusahaan. Keberlangsungan hidup perusahaan merupakan pertimbangan utama investor dalam pengambilan keputusan investasi. Menurut Fernández-Guadaño \& Sarria-Pedroza (2018), semakin tinggi aktivitas corporate social responsibility menciptakan 
keberlangsungan hidup perusahaan akan terjaga dalam jangka panjang karena mendapatkan dukungan para pemangku kepentingan, sehingga kecil kemungkinan perusahaan mengalami kebangkrutan.

Beberapa penelitian seperti Kim, Park, \& Wier (2012) dan Dharma \& Noviari (2017) menekankan pada manfaat jangka panjang jika perusahaan aktif melakukan aktivitas corporate social responsibility. Perusahaan yang konsisten melakukan corporate social responsibility yang berkualitas cenderung tidak melakukan rekayasa laba untuk menciptakan informasi laba yang berkualitas. Perusahaan lebih memprioritaskan pencipataan nilai jangka panjang dengan mengedepankan aspek etika dalam menjalankan bisnis.

\section{Pengaruh Tax Avoidance Terhadap Value Creation}

Penelitian ini menjelaskan bahwa tax avoidance memiliki pengaruh positif terhadap value creation. Tax avoidance yang agresif menghasilkan laba setelah pajak tinggi sehingga menjadi informasi menarik dan berharga bagi investor potensial sebelum melakukan pengambilan keputusan investasi. Hal tersebut dinyatakan juga oleh Chasbiandani \& Martani (2012), bahwa dalam jangka panjang tax avoidance akan meningkatkan nilai perusahaan. Selain itu, pandangan perusahaan terhadap tax avoidance memberikan manfaat ekonomi yang besar dan sumber pembiayaan yang tidak mahal, sehingga ada upaya-upaya melakukan tax avoidance setidaknya sebagai sumber pemibiayaan yang dapat mengurangi penggunaan utang (Graham \& Tucker, 2006). Beberapa penelitian seperti Hanlon \& Slemrod (2009) menyatakan bahwa penghindaran pajak agresif dapat mempengaruhi nilai saham karena membuat harga saham perusahaan lebih menarik karena nilai laba perusahaan akan lebih maksimal. Dalam pandangan tradisional, tax avoidance justru akan meningkatkan nilai perusahaan, jika pengelolaan manajemen dalam perusahaan tersebut berjalan dengan baik (Desai \& Dharmapala, 2009; Zeng, 2014).

\section{Corporate Social Responsiblity dan Tax Avoidance memediasi hubungan antara Corporate Governance terhadap Value Creation.}

[a2] Uji Sobel dinyatakan signifikan apabila hasil dari Sobel Test >1,98. Berdasarkan hasil perhitungan uji Sobel, dapat disimpulkan bahwa nilai tax avoidance adalah 4,299 yang artinya tax avoidance memiliki pengaruh mediasi pada hubungan good governance dan value creation. Good governance diimplementasikan sebagai suatu sistem pengelolaan bisnis berdasarkan prinsip transparansi, akuntabilitas, kemandirian, dan kesetaraan ternyata tidak mampu mengantisipasi motivasi binsis perusahaan untuk memaksimalkan laba secara agresif melalui tax avoidance. Dari sudut pandang pembiayaan, tax avoidance dipandang sebagai sumber pembiayaan yang murah dan tidak membutuhkan cost of debt yang tinggi dan terhindar dari risiko kebangkrutan (Graham \& Tucker, 2006).

Selain itu tax avoidance menurut perusahaan dapat memberikan manfaat jangka panjang berupa penciptaan nilai perusahaan (Chasbiandani \& Martani, 2012). Persoalan asimetri informasi dalam penelitian ini menjadi konflik yang belum terselesaikan melalui implementasi good governance karena adanya perbedaan kepentingan (Shahin \& Zairi, 2007). Berdasarkan hasil uji mediasi ini, dapat dilihat motivasi tax avoidance perusahaan melemahkan tata kelola perusahaan. Keberadaan fungsi pengawas melalui peran dewan komisaris tidak mampu mengantisipasi keinginan kuat untuk memaksimalkan laba dalam rangka memberikan sinyal laba positif kepada para investor di bursa saham (Santa \& Rezende, 2016). 
Hasil uji sobel untuk pengaruh mediasi berikutnya diketahui nilai corporate social responsibility sebesar $(-5,828)$ dapat menjelaskan bahwa corporate social responsibility tidak memediasi hubungan good corporate governance dan value creation. Artinya corporate social responsibility dianggap bukan fokus utama dalam meningkatkan nilai perusahaan, sehingga dewan direksi dan komisaris dalam suatu perusahaan tidak memperhatikan pentingnya corporate social responsibility karena dianggap corporate social responsibility membutuhkan alokasi dana yang banyak. Corporate social responsibility yang dilakukan perusahaan masih sebatas dilaksanakan karena kerelaan bukan karena kewajiban.

\section{SIMPULAN}

Implementasi tata kelola perusahaan yang baik atau good governance diyakini mampu mengatur dan mengendalikan perusahaan untuk menciptakan nilai tambah (value added) bagi semua stakeholders. Demikian juga hasil penelitian ini yang membuktikan bahwa good governance dapat meningkatkan value creation perusahaan. Termasuk bagian dari pelaksanaan prinsip good corporate governance adalah pelaksanaan aktivitas-aktivitas tanggung jawab sosial atau corporate social responsibility sebagai kontraprestasi perusahaan kepada para stakeholders yang juga terbukti mampu meningkatkan nilai perusahaan. Hanya saja, tidak dapat dipungkuri ada upaya-upaya perusahaan untuk meningkatkan nilai perusahaan melalui tax avoidance. Hal tersebut juga terbukti dalam penelitian ini bahwa meskipun perusahaan telah mengimplementasikan sistem good corporate governance, namun upaya memaksimalkan laba perusahaan melalui tax avoidance masih tinggi. Pada sisi yang lain, hasil penelitian ini menjelaskan adanya pengaruh positif pelaksanaan aktivitas corporate social responsibility terhadap nilai perusahaan. Hasil penelitian ini menjelaskan adanya motivasi melakukan corporate social responsibility untuk menutupi tindakan agresif tax avoidance perusahaan untuk meningkatkan nilai perusahaan.

Adanya anggapan bahwa pajak itu beban yang akan mengganggu cash flow perusahaan, menempatkan perusahaan pada posisi dilema. Pada satu sisi, perusahaan diperhadapkan pada tugas dan tanggung jawab untuk mengelola bisnisnya dengan mengedepankan prinsip-prinsip etika secara etis, keterbukaan, akuntabilitas, kemandirian, dan kesetaraan. Tetapi, tidak dapat dipungkiri bahwa faktor sinyal kuat informasi laba bagi pasar menjadi motivasi perusahaan melakukan tax avoidance. Berdasarkan hasil penelitian ini, regulator terkait, yaitu pemerintah perlu menelaah kembali penyelesaian kewajiban perpajakan perusahaan-perusahaan yang telah mengimplementasikan dan melaksanakan good corporate govenance dan corporate social responsibility sebagai cara untuk melakukan uji kepatuhan dalam rangka antisipasi tax avoidance yang agresif.

Kebijakan implementasi good corporate governance yang bersifat mandatory bagi perusahaan go public, tidak menjamin bahwa perusahaan melaksanaan kepatuhan perpajakan. Oleh karena itu, pemerintah dipandang perlu melakukan mekanisme pengawasan yang lebih antisipatif terhadap motivasi perusahaan untuk meningkatkan nilai perusahaan dengan cara yang bertentangan dengan ketentuan yang berlaku.

Penelitian ini juga memiliki keterbatasan yaitu data yang digunakan tidak sepenuhnya dapat membuktikan pengaruh anatar variabel dikarenakan beberapa indikator variabel tidak dilaporkan dalam laporan keuangan. Penelitian selanjutnya disarankan dapat menambahkan variabel lainnya yang berhubungan dengan good corporate governance, corporate social responsibility, value creation, dan tax avoidance. Sehingga dapat memberikan gambaran dan pengertian yang lebih luas mengenai 
faktor apa saja yang mempengaruhi tax avoidance selain good corporate governance, corporate social responsibility, dan value creation.

\section{DAFTAR PUSTAKA}

Ammann, M., Oesch, D., \& Schmid, M. M. (2010). Corporate Governance and Firm Value: International Evidence. Journal of Empirical Finance, 18(1), 36-55.

Brown, J. A., \& Forster, W. R. (2013). CSR and Stakeholder Theory: A Tale of Adam Smith. Journal of Business Ethics, 112(2), 301-312.

Chasbiandani, T., \& Martani, D. (2012). Pengaruh Tax Avoidance Jangka Panjang Terhadap Nilai Perusahaan. Simposium Nasional Akuntansi XV.

Desai, M. A., \& Dharmapala, D. (2009). Corporate Tax Avoidance And Firm Value. The Review of Economics and Statistics, 91(3), 537-546.

Dewi, G. A. P., \& Sari, M. M. R. (2015). Pengaruh Insentif Eksekutif , Corporate Risk dan Corporate Governance pada Tax Avoidance. E-Jurnal Akuntansi Udayana, 13(1), 50-67.

Dharma, N. B. S., \& Noviari, N. (2017). Pengaruh Corporate Social Responsibility Dan Capital Intensity Terhadap Tax Avoidance. E-Jurnal Akuntansi Universitas Udayana, 18(1), 529-556.

Dyreng, S. D., Hanlon, M., \& Maydew, E. L. (2008). Long-Run Corporate Tax Avoidance. The Accounting Review, 83(1), 61-82.

Fernández-Guadaño, J., \& Sarria-Pedroza, J. H. (2018). Impact of Corporate Social Responsibility on value creation from a stakeholder perspective. Sustainability, 10(6), 2-10.

Gholami, S. (2011). Value Creation Model through Corporate Social Responsibility (CSR). International Journal of Business and Management, 6(9), 148-154.

Graham, J. R., \& Tucker, A. L. (2006). Tax Shelters And Corporate Debt Policy. Journal of Financial Economics, 81(3), 563-594.

Hanlon, M., \& Slemrod, J. (2009). What Does Tax Aggressiveness Signal ? Evidence From Stock Price Reactions To News About Tax Shelter Involvement. Journal of Public Economics, 93(1-2), 126-141.

Hasan, A., \& Butt, S. A. (2009). The Effect of Corporate Governance and Ownership Structure on Capital Structure of Iranian Listed Companies. International Journal of Business and Management, 4(2), 50-57.

Husted, B. W., \& Allen, D. B. (2007). Strategic Corporate Social Responsibility and Value Creation Among Large Firms Lessons from the Spanish Experience. Long Range Planning, 40, 594-1040.

Jensen, C., \& Meckling, H. (1976). Theory Of The Firm: Managerial Behavior, Agency Costs And Ownership Structure. Journal of Financial Economics, 3(4), 305-360.

Kiesewetter, D., \& Manthey, J. (2017). Tax avoidance, value creation and CSR - a European perspective. Corporate Governance: The International Journal of Business in Society, 17(5), 803-821.

Kim, J. B., Li, Y., \& Zhang, L. (2011). Corporate Tax Avoidance And Stock Price Crash Risk: Firm-Level Analysis. Journal of Financial Economics, 100(3), 639-662.

Kim, Y., Park, M. S., \& Wier, B. (2012). Is Earnings Quality Associated with Corporate Social Responsibility? The Accounting Review, 87(3), 761-796.

Lanis, R., \& Richardson, G. (2011). The Effect Of Board Of Director Composition On Corporate Tax Aggressiveness. Journal of Accounting and Public Policy, 30, 50-70.

Mahrani, M., \& Soewarno, N. (2018). The Effect Of Good Corporate Governance Mechanism And Corporate Social Responsibility On Financial Performance With Earnings Management As Mediating Variable. Asian Journal of Accounting 
Research, 3(1), 41-60.

Muryati, N. N. T. S., \& Suardikha, I. M. S. (2014). Pengaruh Corporate Governance Pada Nilai Perusahaan. E-Jurnal Akuntansi Universitas Udayana 9.2, 9(2), 411-429.

Purbopangestu, H. W., \& Subowo. (2014). Pengaruh Good Corporate Governance Terhadap Nilai Perusahaan Dengan Corporate Social Responsibility Sebagai Variabel Intervening. Accounting Analysis Journal, 3(3), 321-333.

Ramdhaningsih, A., \& Utama, I. M. K. (2013). Pengaruh Indikator Good Corporate Governance Dan Profitabilitas Pada Pengungkapan Corporate Social Responsibility. E-Jurnal Akuntansi Universitas Udayana, 3(2), 368-386.

Retno M., R. D., \& Priantinah, D. (2012). Pengaruh Good Corporate Governance Dan Pengungkapan Corporate Social Responsibility Terhadap Nilai Perusahaan (Studi Empiris Pada Perusahaan Yang Terdaftar Di Bursa Efek Indonesia Periode 20072010). Jurnal Nominal, 1(1), 84-103.

Richardson, G., Taylor, G., \& Lanis, R. (2013). The Impact of Risk Management and Audit Characteristics on Corporate Tax Aggressiveness: An Empirical Analysis Abstract. Journal Accounting Public Policy, 32(3), 68-88.

Said, R., Joseph, C., \& Sidek, N. Z. M. (2017). Corporate Governance And Corporate Social Responsibility (CSR) Disclosure: The Moderating Role Of Cultural Values. Developments in Corporate Governance and Responsibility, 5(2), 189-206.

Santa, S. L. L., \& Rezende, A. J. (2016). Corporate Tax Avoidance And Firm Value: From Brazil. SSRN Electronik Journal, 13(30), 114-133.

Shahin, A., \& Zairi, M. (2007). Corporate Governance As A Critical Element For Driving Excellence In Corporate Social Responsibility. International Journal of Quality and Reliability Management, 24(7), 753-770.

Sherman, W. R. (2010). Measuring And Communicating The Value Created By An Organization. American Journal of Business Education (AJBE), 3(5), 87-98.

Stuebs, M., \& Sun, L. (2015). Corporate Governance And Social Responsibility. International Journal of Law and Management, 57(1), 38-52.

Sudiyatno, B., \& Puspitasari, E. (2010). Tobin's Q Dan Altman Z-Score Sebagai Indikator Pengukuran Kinerja Perusahaan. Kajian Akuntansi, 2(1), 9-21.

Susanti, S. I. A. (2011). Pengaruh Kualitas Corporate Governance, Kualitas Audit, dan Earnings Management Terhadap Kinerja Perusahaan. Jurnal Ekonomi Dan Bisnis, 5(2), 145-161.

Wahyudin, A., \& Solikhah, B. (2017). Corporate Governance Implementation Rating in Indonesia and Its Effects on Financial Performance. Corporate Governance: The International Journal of Business in Society, 17(2), 250-265.

Zeng, T. (2014). Derivative Financial Instruments , Tax Aggressiveness and Firm Market Value. Journal of Financial Economic Policy, 6(4), 376-390. 